\title{
THE REVIEW OF ERgONOMICS ANALYSIS FOR BOdy Postures ASSESSMENT
}

\author{
VuJiCA HERZOG, N. \& BUCHMEISTER, B.
}

Abstract: The number of work-related musculoskeletal disorders is still increasing and since these injuries cause high costs for companies and whole society it is important to prevent them through ergonomic analysis and workplace design. Methods for assessing external load are numerous and they differ in the stages of assessment. They also differ in the body area they assess (the load of the back, the upper and lower limbs independently or provide a total assessment) and the types of work tasks they focus on. In the paper the review of the most common methods for assessing body postures is presented. Beside generally known methods such as OWAS, RULA, REBA, NIOSH and others also newly methods usually developed in companies for specific purposes are discussed such as PEIL, ERIN and Ergocheck. Since methods are usually dedicated to a restricted type of work task and restricted body area the review of different ergonomics analysis could be of benefit.

Key words: ergonomics, workplace design, body postures, assessment methods
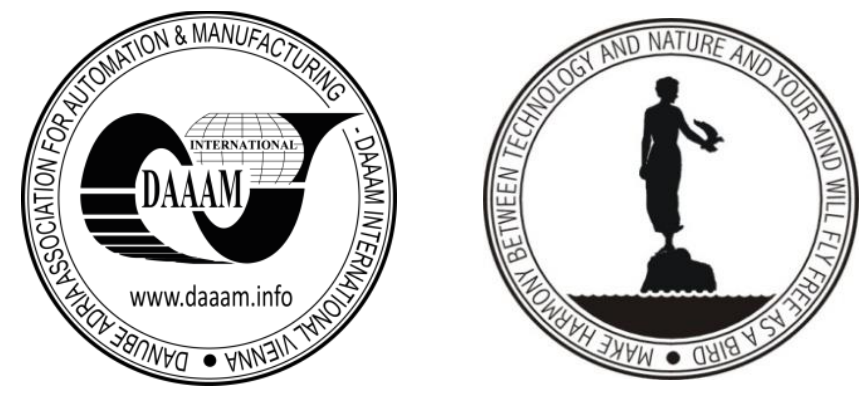

Authors' data: Asist. Prof. Dr. Sc. Vujica Herzog, N[atasa], Assoc. Prof. Dr. Sc. Buchmeister, B[orut]; University of Maribor, Faculty of Mechanical Engineering, Production Engineering Institute, Smetanova 17, 2000 Maribor, Slovenia, natasa.vujica@um.si,borut.buchmeister@um.si

This Publication has to be referred as: Vujica Herzog, N[atasa] \& Buchmeister, B[orut] (2015). The Review of Ergonomics Analysis for Body Postures Assessment, Chapter 14 in DAAAM International Scientific Book 2015, pp.153-164, B. Katalinic (Ed.), Published by DAAAM International, ISBN 978-3-902734-05-1, ISSN 17269687, Vienna, Austria

DOI: 10.2507/daaam.scibook.2015.14 
Vujica Herzog, N. \& Buchmeister, B.: The Review of Ergonomics Analysis for Bo...

\section{Introduction}

Ergonomics deals with the exploration of human physical and mental capabilities during working and adjusting the working load. By using ergonomic arrangement of the workplace it is possible to adapt work to a human's physical and mental characteristics and to reduce or prevent adverse effects on health (Polajnar et al., 2010; Andrejiova et al., 2012). Correct designing of the workplace also includes human habits to ensure humans' work as productively effectively, and safely as possible.

The two most important factors that influence stress at work can be divided into:

1. Working environments with working conditions such as noise, heat, humidity, illumination, air velocity and

2. Body postures; numerous studies confirmed the relationship between the risks for developing musculoskeletal disorders (MDS) and awkward postures.

The number of existing ergonomics methods for assessing body postures is many and they vary in the area of the body they assess (Roman-Liu, 2014). Some methods assess the load on selected body part independently of each other and other methods provide a total assessment. Some methods focus on different work tasks such as repetitive and non-repetitive tasks and there are methods that evaluate static load e.g. load sustaining the same posture for a long time. Manual handling is another type of tasks that should be especially consider.

Beside manual evaluation tools which are time consuming there exist also several computer aided tools that shorten evaluation time and usually offer several methods for body evaluation.

According to available literature the number of usually used methods is more than thirty and of course a question appear 'Which method should be used for certain work type?'

\section{Methods for assessing body postures}

\subsection{OWAS Method}

Since OWAS, RULA and REBA are generally know methods we will make a short overview of these methods first.

The OWAS method (Ovaco Working Analyzing System) is a method of posture monitoring (Karhu et al., 1977 and 1981). This method originated from Finland's steel industry where the body positions of workers were analyzed. Since the method was initially successful it was further developed and modified. It is considered to be a practical method for identifying and evaluating working postures. The OWAS procedure consists of two parts: an observational technique for classifying body postures, and a set of criteria for the redesigning of working methods and workplaces. Body postures are classified into 28 positions including the positions of the back (four positions), upper limbs (four), hands (three), lower limbs (nine), head and neck (five), as well as the load or force handled (three).

Each of these positions has pre-defined high risk and low risk postures that are coded by the observer. After calculating the amount of time the worker maintains these postures, the final step is to assign a four-level action code for task improvement 
(changes are not needed, changes needed immediately, changes needed in near future and needed intensive observation).

An example of OWAS method is present used for researching saleswoman movements at work (Fig. 1).

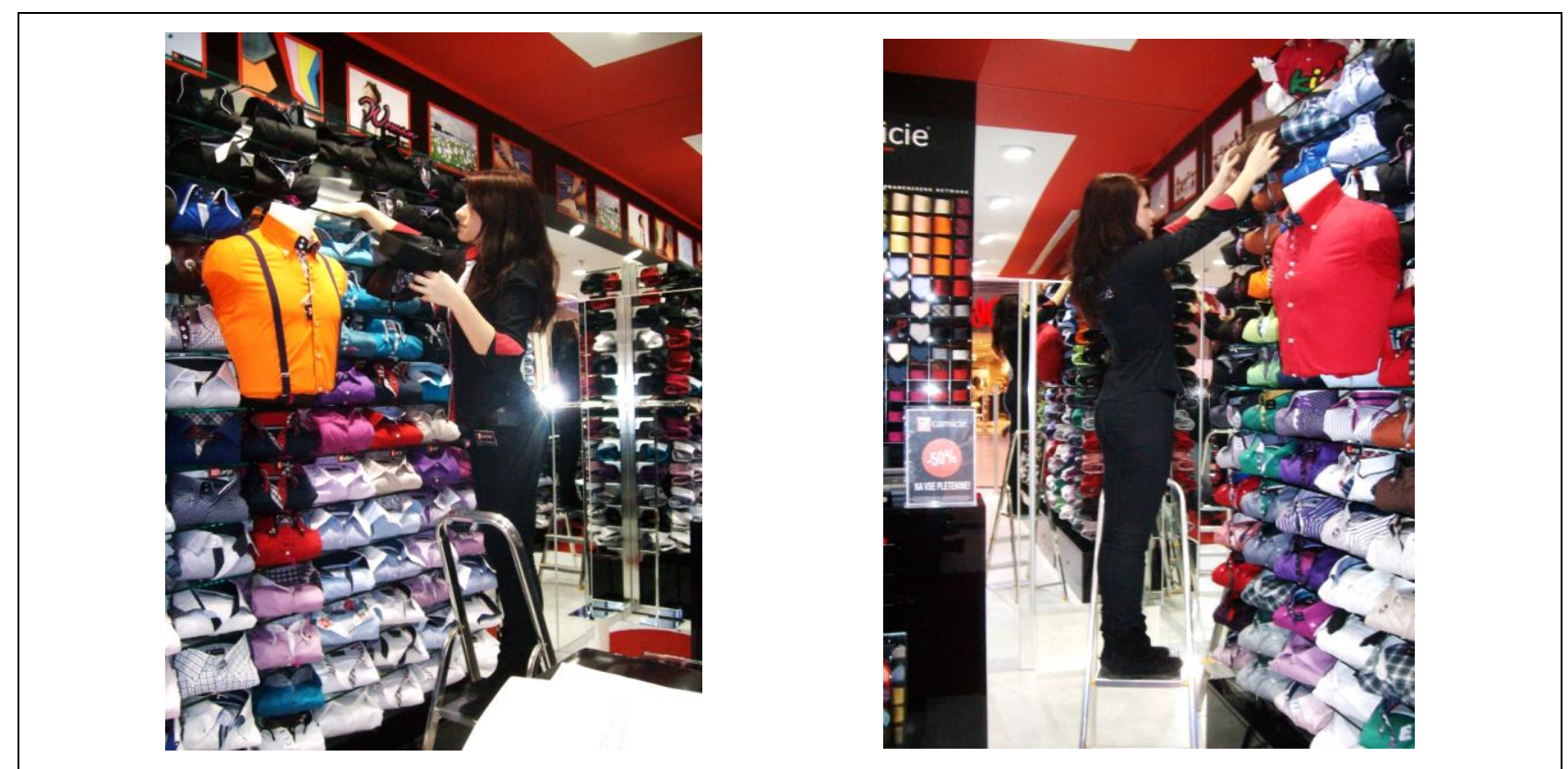

Fig. 1. Saleswoman movements at work - uploading the material onto the shelves with the help of a ladder

Table 1 presents results of OWAS observation method with the calculated percentage of each position (Equation 1) and the time of duration (Equation 2) where $\sum \mathrm{F}_{\mathrm{p}}$ stands for the sum of each body position, and $\left(\sum \mathrm{F}_{\mathrm{s}}\right)$ is the sum of all body positions within each group of working positions.

\begin{tabular}{|c|c|c|c|c|c|c|c|c|c|c|c|c|c|c|c|c|c|c|}
\hline \multirow{3}{*}{$\begin{array}{l}\text { Body } \\
\text { Parts }\end{array}$} & \multicolumn{3}{|c|}{$\begin{array}{c}\text { Thoraxlumb. } \\
\text { spine }\end{array}$} & \multicolumn{4}{|c|}{ Upper limb } & \multicolumn{3}{|c|}{ Hands } & \multicolumn{3}{|c|}{ Lower limb } & \multicolumn{5}{|c|}{ Head } \\
\hline & 1.1 & 1.2 & 1.3 & 2.1 & 2.2 & 2.3 & 2.4 & 3.1 & 3.2 & 3.3 & 4.2 & 4.3 & 4.6 & 5.1 & 5.2 & 5.3 & 5.4 & 5.5 \\
\hline & \{ & ? & $\cdot \hat{L}$ & o & 果. & i & .9 & $\triangle$ & $\Lambda$ & $\angle$ & 9 & 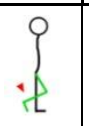 & q & 9 & 1.0 & 1.8 & 9 & d \\
\hline $\begin{array}{l}\text { Nr. of } \\
\text { measur. }\end{array}$ & 110 & 90 & 48 & 78 & 30 & 80 & 60 & 108 & 72 & 42 & 100 & 82 & 66 & 80 & 58 & 52 & 58 & 40 \\
\hline$p_{i}[\%]$ & 40.3 & 36.3 & 19.3 & 31.5 & 12.1 & 32.2 & 24.2 & 48.6 & 32.4 & 18.9 & 40.3 & 33.0 & 26.6 & 32.2 & 23.4 & 20.9 & 23.4 & 11.1 \\
\hline$t_{p i}[\min$ & 145.1 & 130.7 & 69.5 & 113.4 & 43.6 & 115.9 & 87.1 & 175 & 116.6 & 68.0 & 145.1 & 118.8 & 95.8 & 115.9 & 84.2 & 75.2 & 84.2 & 40 \\
\hline Measure & 口 & $\bullet$ & 口 & $\square$ & $\square$ & & $\bullet$ & 口 & 口 & $\square$ & 口 & 9 & 口 & $\square$ & $\bullet$ & $\bullet$ & $\bullet$ & 口 \\
\hline
\end{tabular}

Tab. 1. OWAS - calculated results with recommended measures

$$
\begin{aligned}
& p=\frac{\sum F_{p} \cdot 100}{\sum \mathrm{F}_{s}}\lceil \%\rceil \\
& t_{p}=\frac{450 \cdot p}{100}\lceil\mathrm{~min}\rceil
\end{aligned}
$$


Vujica Herzog, N. \& Buchmeister, B.: The Review of Ergonomics Analysis for Bo...

The obtained results are compared with the recommended measurement values (Table 2) and the results are presented with signs in Table 1 and in the histogram (Figure 2).

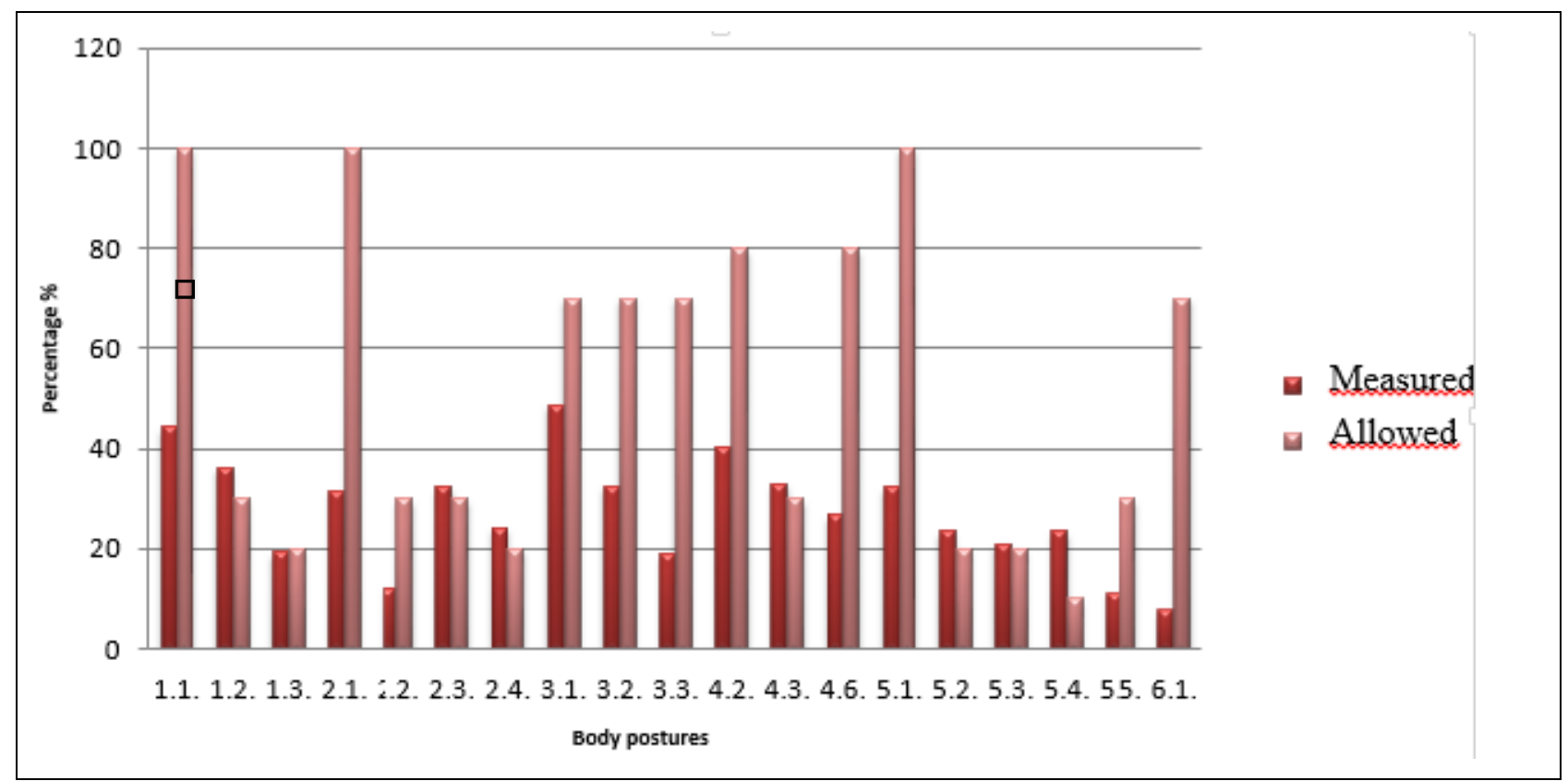

Fig. 2. The histogram of the OWAS results applied at the inspected workplace of the saleswoman

\begin{tabular}{|c|c|c|c|c|c|c|c|c|c|c|c|c|c|c|c|c|c|c|c|}
\hline $\begin{array}{l}\text { Body } \\
\text { Parts }\end{array}$ & \multicolumn{4}{|c|}{$\begin{array}{c}\text { Thoraxlumbal } \\
\text { spine }\end{array}$} & \multicolumn{4}{|c|}{ Upper limb } & \multicolumn{3}{|c|}{ Hands } & \multicolumn{3}{|c|}{ Lower limb } & \multicolumn{5}{|c|}{ Head } \\
\hline & 1.1 & 1.2 & 1.3 & 1.4 & 2.1 & 2.2 & 2.3 & 2.4 & 3.1 & 3.2 & 3.3 & 4.2 & 4.3 & 4.6 & 5.1 & 5.2 & 5.3 & 5.4 & 5.5 \\
\hline $\begin{array}{c}\text { OWAS } \\
\%\end{array}$ & L & i & -0 & $\therefore$ & 六 & 우. & ? & .9. & $\triangle$ & $\Lambda$ & $\angle$ & 9 & it & . & 9 & 1.0 & 1.9 & 9 & b. \\
\hline 10 & $\square$ & $\square$ & 口 & $\bullet$ & $\square$ & $\square$ & 口 & $\square$ & $\square$ & $\square$ & $\square$ & $\square$ & $\square$ & $\square$ & $\square$ & $\square$ & $\square$ & ㅁ & $\square$ \\
\hline 20 & $\square$ & $\square$ & $\square$ & $\bullet$ & 口 & $\square$ & 口 & 口 & $\square$ & $\square$ & $\square$ & 口 & $\square$ & $\square$ & $\square$ & $\square$ & $\square$ & - & $\square$ \\
\hline 30 & $\square$ & $\square$ & $\bullet$ & $\bullet$ & $\square$ & $\square$ & $\square$ & $\bullet$ & $\square$ & $\square$ & $\square$ & $\square$ & $\square$ & $\square$ & $\square$ & $\bullet$ & $\bullet$ & $\bullet$ & $\square$ \\
\hline 40 & $\square$ & $\bullet$ & $\bullet$ & $\bar{\Delta}$ & $\square$ & $\bullet$ & $\bullet$ & $\bullet$ & $\square$ & $\square$ & $\square$ & $\square$ & $\bullet$ & $\square$ & $\square$ & $\bullet$ & $\bullet$ & $\bar{\Delta}$ & 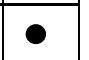 \\
\hline 50 & $\square$ & $\bullet$ & $\bullet$ & $\bar{\Delta}$ & $\square$ & $\bullet$ & $\bullet$ & $\bullet$ & $\square$ & $\square$ & 口 & $\square$ & $\bullet$ & $\square$ & $\square$ & $\bullet$ & $\bullet$ & $\bar{\Delta}$ & 0 \\
\hline 60 & 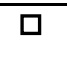 & $\bullet$ & $\bar{\Delta}$ & $\bar{\Delta}$ & $\square$ & $\bullet$ & $\bullet$ & $\bullet$ & $\square$ & $\square$ & D & प & $\bullet$ & $\square$ & प & $\Delta$ & $\bar{\Delta}$ & $\bar{\Delta}$ & $\bullet$ \\
\hline 70 & 口 & $\bullet$ & $\bar{\Delta}$ & $\bar{\Delta}$ & $\square$ & $\bullet$ & $\bullet$ & $\bar{\Delta}$ & $\square$ & $\square$ & $\square$ & $\square$ & $\bullet$ & 口 & $\square$ & $\bar{\Delta}$ & $\bar{\Delta}$ & $\bar{\Delta}$ & $\bullet$ \\
\hline 80 & $\square$ & $\bar{\Delta}$ & $\bar{\Delta}$ & $\bar{\Delta}$ & $\square$ & $\bar{\Delta}$ & $\bar{\Delta}$ & $\overline{\Delta \Delta}$ & $\star$ & $\star$ & $\star$ & $\square$ & $\bar{\Delta}$ & $\square$ & $\square$ & $\bar{\Delta}$ & $\bar{\Delta}$ & $\bar{\Delta}$ & $\bar{\Delta}$ \\
\hline 90 & $\square$ & $\bar{\Delta}$ & $\bar{\Delta}$ & $\bar{\Delta}$ & $\square$ & $\overline{\Delta \Delta}$ & $\bar{\Delta}$ & $\overline{\Delta \Delta}$ & $\star$ & $\star$ & $\star$ & $\bullet$ & $\overline{\Delta \Delta}$ & $\bullet$ & $\square$ & $\bar{\Delta}$ & $\bar{\Delta}$ & $\bar{\Delta}$ & $\bar{\Delta}$ \\
\hline 100 & $\square$ & $\bar{\Delta}$ & $\boldsymbol{\Delta}$ & $\Delta$ & $\square$ & $\mathbf{\Delta}$ & $\bar{\Delta}$ & $\Delta$ & $\star$ & $\star$ & $\star$ & $\bullet$ & $\bar{\Delta}$ & $\bullet$ & $\square$ & $\Delta$ & $\bar{\Delta}$ & $\overline{\Delta \Delta}$ & $\mathbf{\Delta}$ \\
\hline
\end{tabular}

Legend for Table 2: $\square$ - changes are not needed $\boldsymbol{\Delta}$ - changes needed immediately - - changes needed in near future $\star$ - needed intensive observation

Tab. 2. OWAS - review table of recommended measures

\subsection{RULA}

The Rapid Upper Limb Assessment (RULA) was developed by Dr. Lynn McAtamney and Dr. Nigel Corlett (1993). This method evaluates individuals' 
exposures to postures, forces and muscle activities that that have been shown to contribute to Repetitive Strain Injuries. Use of this ergonomic evaluation approach results in a risk score between one and seven, where higher scores signify greater levels of apparent risk. A low RULA score does not guarantee that the workplace is free of ergonomic hazards, and a high score does not assure that a severe problem exists.

An example of using RULA observation method is present at the workplace clinic for argon and YAG laser therapy (Fig.3).

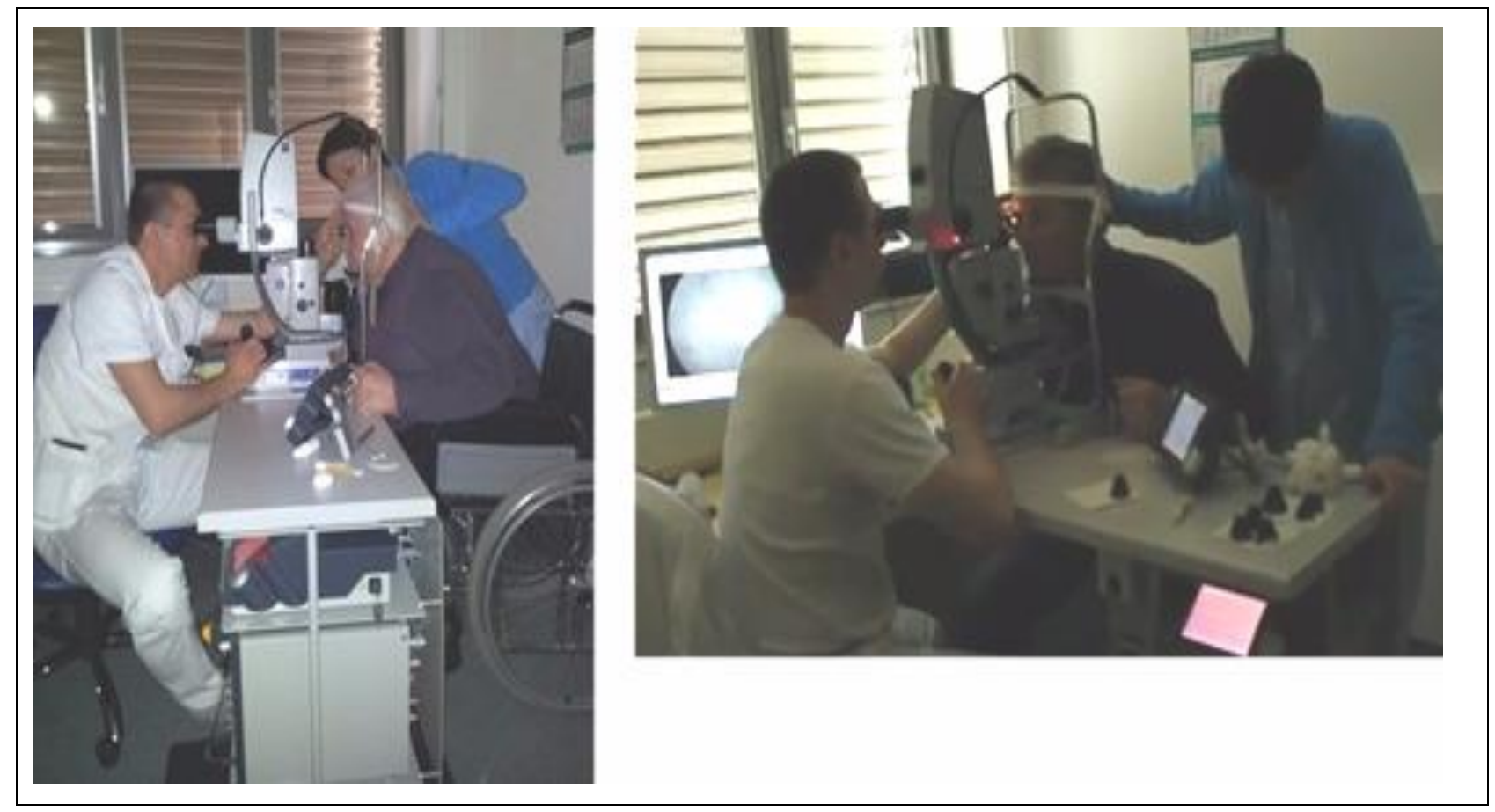

Fig. 3. Doctors' positions at workplace for laser therapy

\subsection{REBA}

REBA (Rapid Entire Body Assessment) was designed in UK to provide a quick and easy observational postural analysis tool for whole body activities in health-care and other service industries (Hignett and McAtamney, 2000).

The basic idea of REBA is to observe positions of individual body segments at work and score them. The greater deviation from neutral posture is the higher will the sore of each body part be. Group A includes trunk, neck, and legs and group B upper arms, lower arms, and wrists. These groups are combined and the 144 posture combinations are transformed to a general postural score called grand score. Scores are compared to tables stating musculoskeletal risk on five levels from negligible to very high and actions needed from none to necessary now.

REBA method can be used in different working fields e.g. in health care, manufacturing, computer work.

An example of workplace for garbage collection is present in Fig. 6 and REBA assessment worksheet for this workplace in Fig. 7. 
Vujica Herzog, N. \& Buchmeister, B.: The Review of Ergonomics Analysis for Bo...

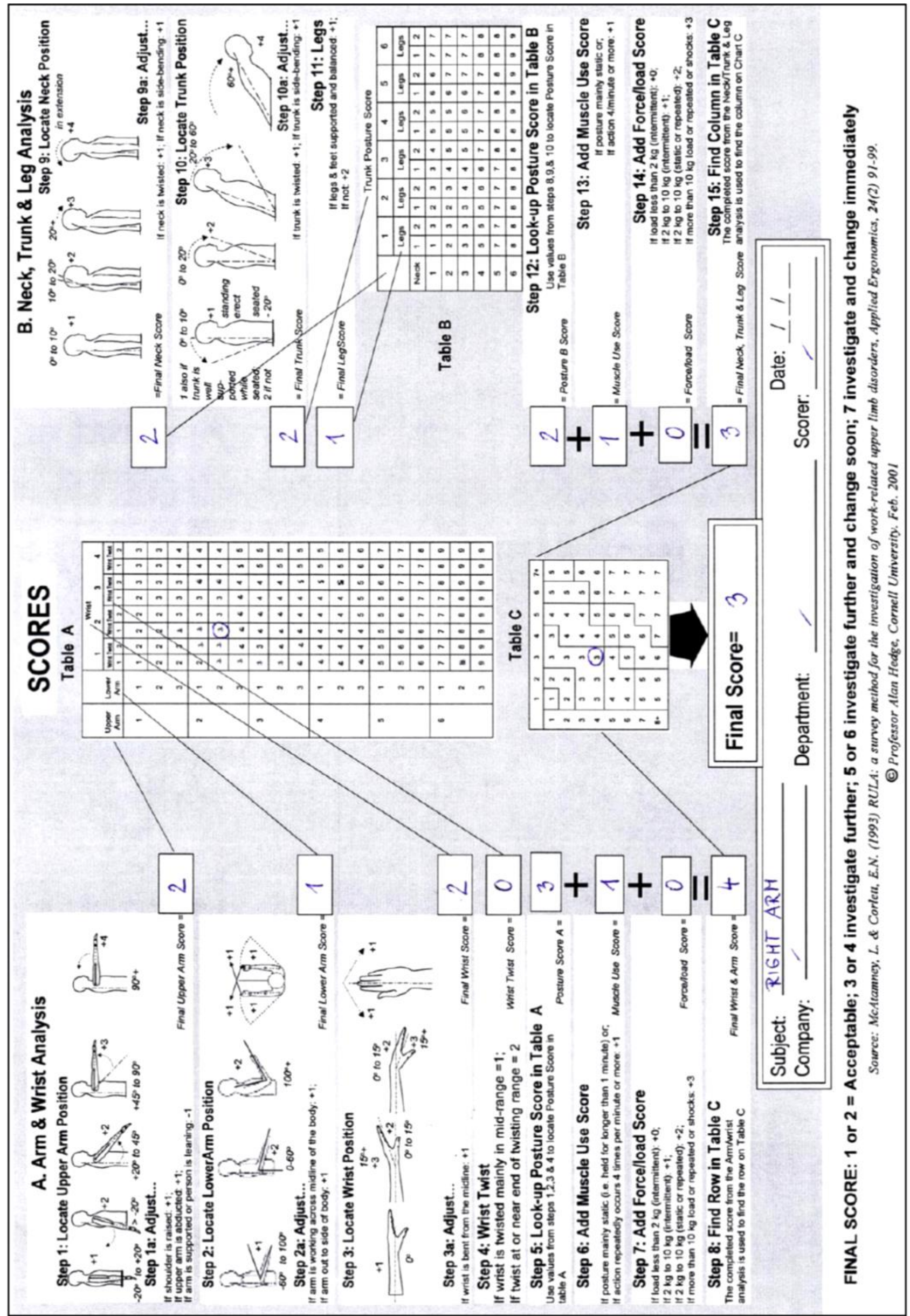

Fig. 4. RULA assessment - right arm 


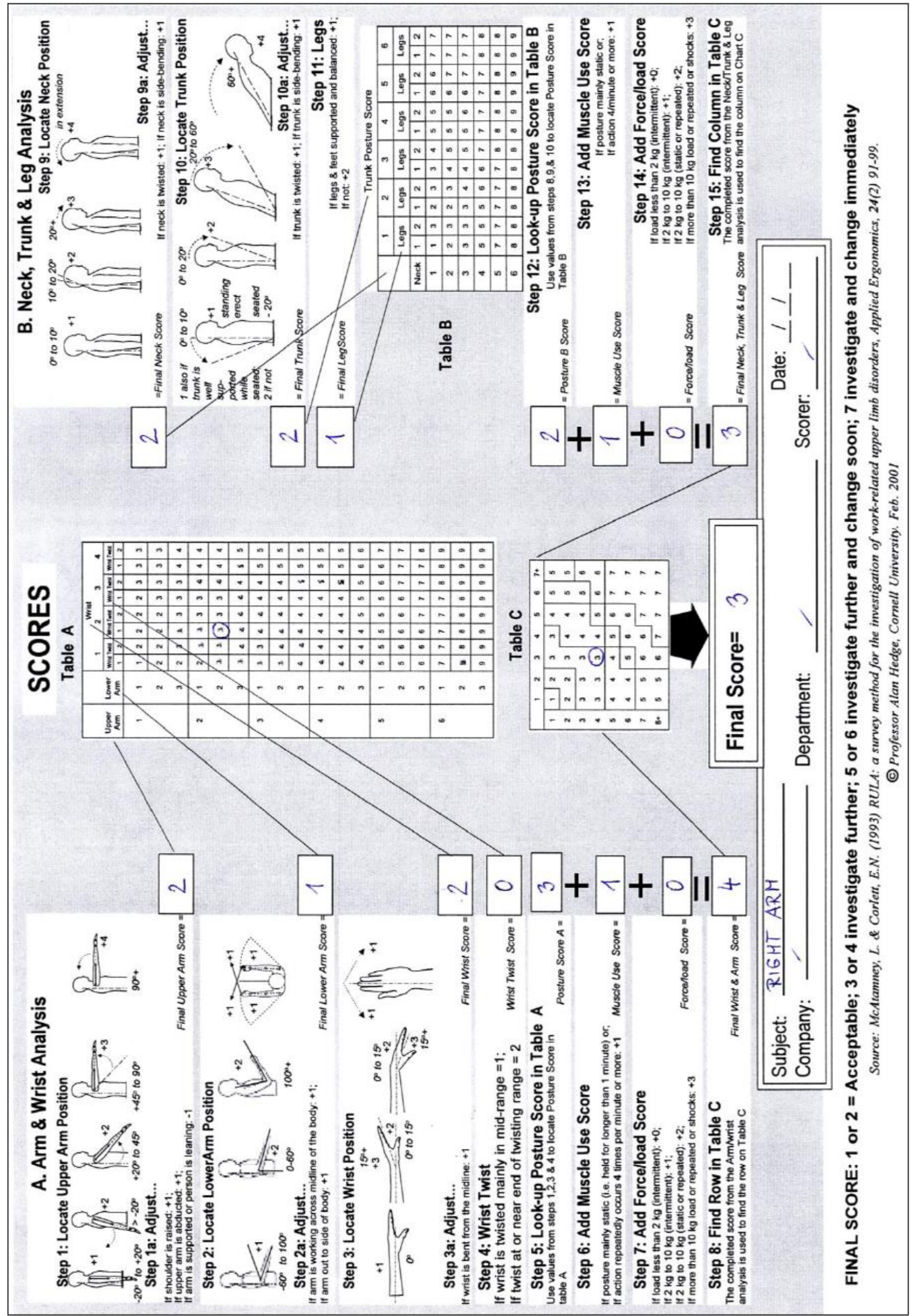

Fig. 5. RULA assessment - left arm 
Vujica Herzog, N. \& Buchmeister, B.: The Review of Ergonomics Analysis for Bo...
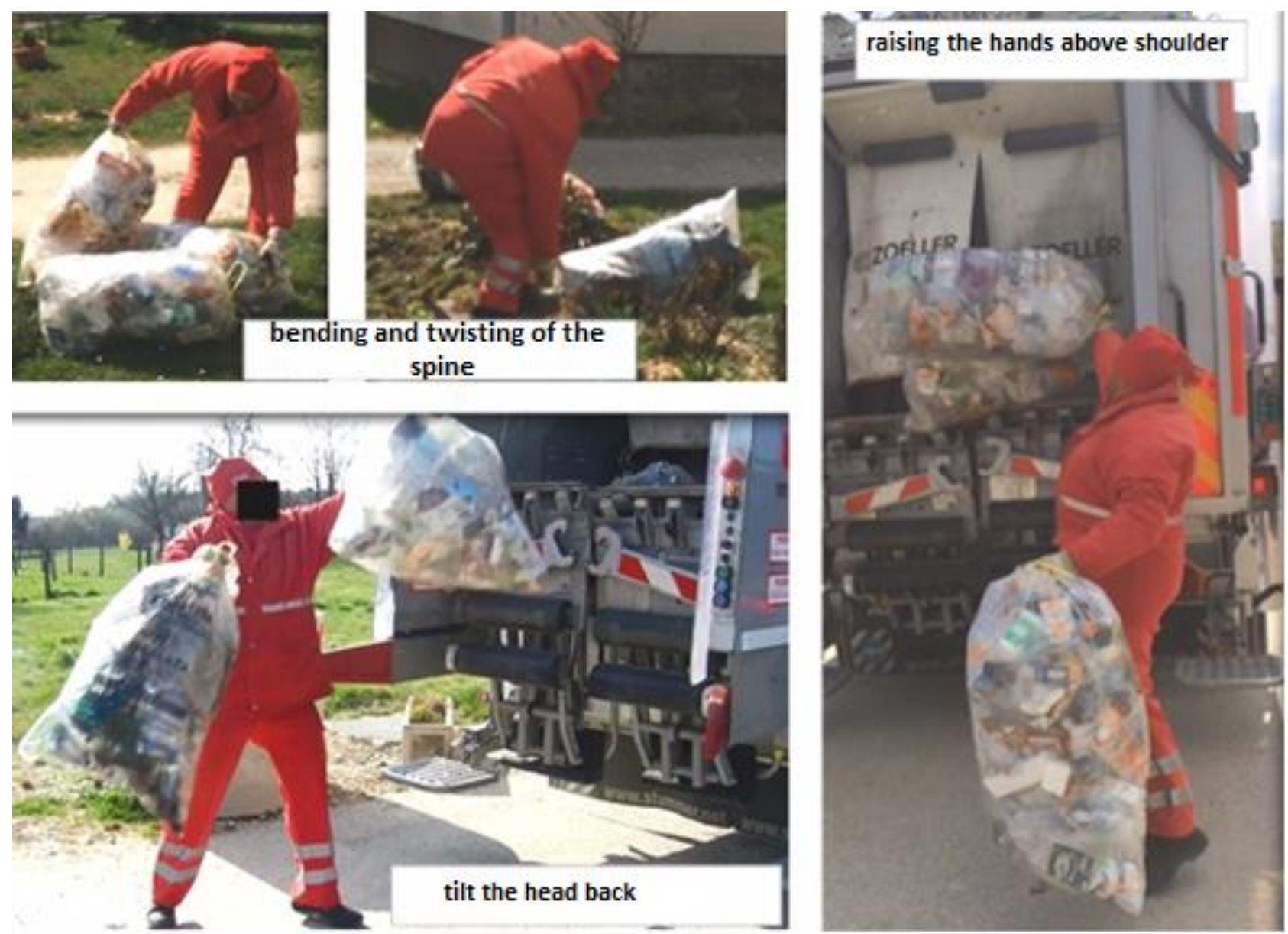

Fig. 6. An example of workplace for garbage collection

\subsection{Other methods}

Besides OWAS, RULA and REBA we selected another six methods and compare them according to body parts they deal with, postures, benefits, limitations and recommendations for use (Tab. 3).

The NIOSH Lifting Equation is a method to assess risk of low-back disorders in jobs with repeated lifting (Waters, 1993). It consists of two primary products, the recommended weight limit and the lifting index. Their objective is to prevent or reduce the occurrence of lifting and lowering overexertion injuries and low back pain among workers.

OCRA is a synthetic index describing risk factors of repetitive actions at work with one figure (Occhipinti E., and Occhipinti et al., 1998 and 2002). The OCRA index quantifies the relationship between the daily numbers of actually performed by the upper limbs in repetitive tasks, and corresponding number of recommend actions. OCRA was developed in Italy to analyze worker's exposure to tasks featuring various upper-limb injury risk factors.

LUBA is a method to code postures of sitting or standing postures by giving additional weights for the postures according to the experimental results of discomfort felt in these postures in individual joints (Kee and Karwowski, 2001 and 2007). All scores are summed up to one score to describe the urgency of actions.

ERIN is a practical tool for assessing work-related musculoskeletal disorders (WMSD). It focuses primarily on physical workplace factors but also includes the 
workers' assessment (Rodrigues et al., 2013). The method was developed in Cuba to prevent WMSDs in Cuba and other developing countries.

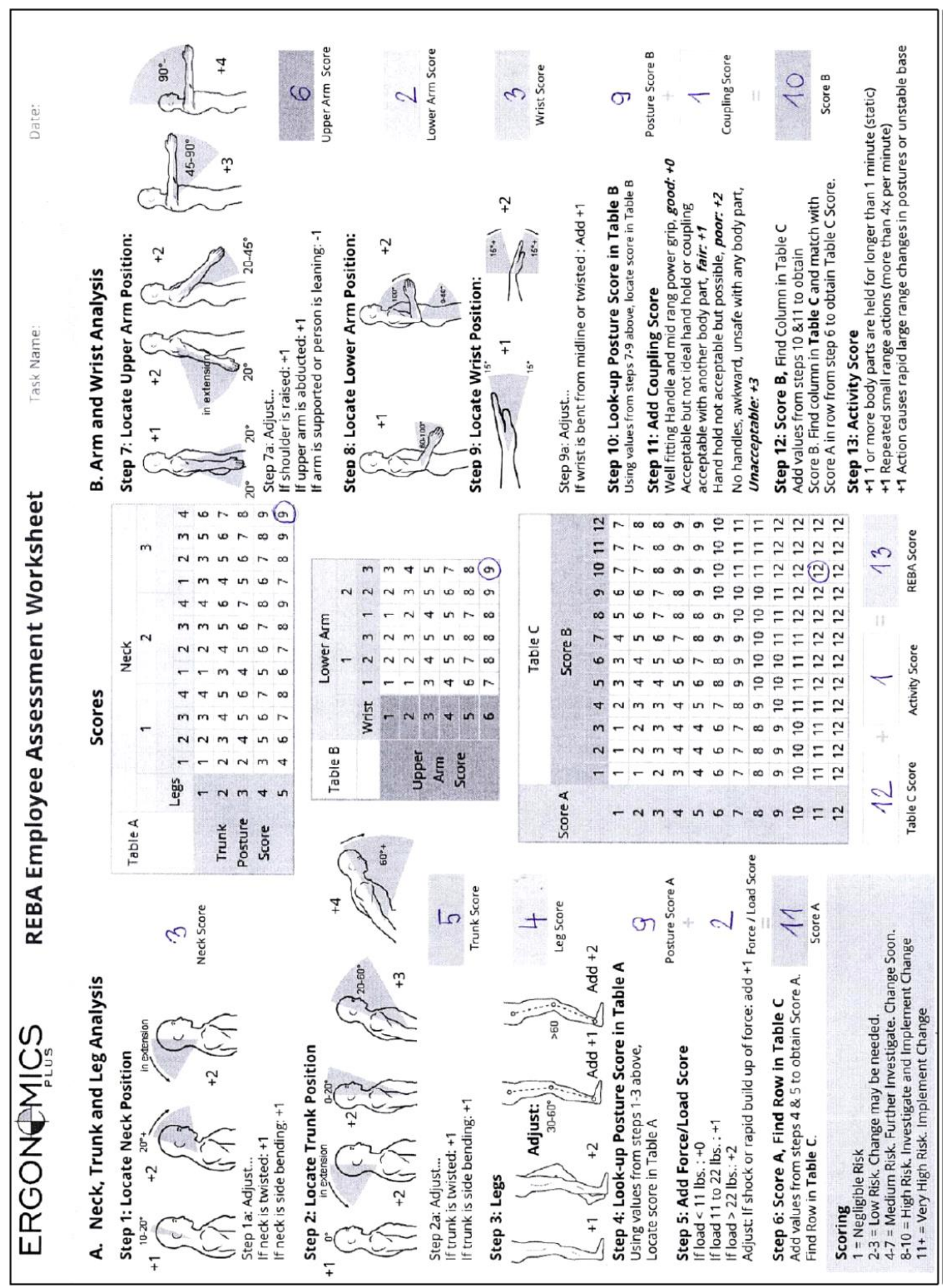

Fig. 7. REBA assessment worksheet (Original worksheet developed by Dr. A. Hedge) 
Vujica Herzog, N. \& Buchmeister, B.: The Review of Ergonomics Analysis for Bo...

\begin{tabular}{|c|c|c|c|c|c|}
\hline Method & $\begin{array}{c}\text { Body } \\
\text { part }\end{array}$ & Postures & Benefits & Limitations & Recommendations \\
\hline OWAS & $\begin{array}{l}\text { Whole } \\
\text { body } \\
\text { load }\end{array}$ & $\begin{array}{l}\text { Back }-7 \\
\text { Upper limb }-4 \\
\text { Arm }-3 \\
\text { Lower limb }-9 \\
\text { Head - } 5\end{array}$ & $\begin{array}{l}\text { Widely used and } \\
\text { documented. }\end{array}$ & $\begin{array}{l}\text { Doesn't separate left and right } \\
\text { upper extremities. Time } \\
\text { consuming. Doesn't consider } \\
\text { repetition or duration of the } \\
\text { sequential postures. Requires } \\
\text { training and specific skills. }\end{array}$ & $\begin{array}{l}\text { For researchers } \\
\text { familiar with the } \\
\text { method }\end{array}$ \\
\hline RULA & $\begin{array}{l}\text { Whole } \\
\text { body } \\
\text { load }\end{array}$ & $\begin{array}{l}\text { Upper arm }-5 \\
\text { Forearm }-3 \\
\text { Wrist }-4 \\
\text { Neck }-4 \\
\text { Trunk }-4 \\
\text { Legs }-2\end{array}$ & $\begin{array}{l}\text { Focus on the most } \\
\text { relevant body } \\
\text { segments. } \\
\text { Easy to use. } \\
\text { Public } \\
\text { computerized } \\
\text { software } \\
\text { available. }\end{array}$ & $\begin{array}{l}\text { Not applicable for tasks } \\
\text { involving manual materials } \\
\text { handling and whole body } \\
\text { movements. Right and left have } \\
\text { to be assessed separately. Does } \\
\text { not consider duration of } \\
\text { exposures. }\end{array}$ & $\begin{array}{l}\text { To Occupational } \\
\text { safety and health } \\
\text { practitioners for } \\
\text { identifying risk for } \\
\text { musculoskeletal } \\
\text { disorders of neck } \\
\text { shoulder and upper } \\
\text { limb. }\end{array}$ \\
\hline REBA & $\begin{array}{l}\text { Whole } \\
\text { body } \\
\text { load }\end{array}$ & $\begin{array}{l}\text { Neck }-4 \text { Trunk } \\
-6 \\
\text { Legs }-4 \\
\text { Upper arm }-6, \\
\text { Forearm }-2, \\
\text { Wrist }-3 \\
\end{array}$ & $\begin{array}{l}\text { Rapid to use. } \\
\text { Computerized } \\
\text { registration. } \\
\text { Public domain. }\end{array}$ & $\begin{array}{l}\text { Time-consuming. Right and left } \\
\text { have to be assessed separately. } \\
\text { Time aspects not considered. }\end{array}$ & $\begin{array}{l}\text { To Occupational } \\
\text { safety/health } \\
\text { practitioners }\end{array}$ \\
\hline NIOSH & $\begin{array}{l}\text { Whole } \\
\text { body } \\
\text { load }\end{array}$ & $\begin{array}{l}\text { Defined by the } \\
\text { horizontal and } \\
\text { vertical position } \\
\text { of the load in } \\
\text { relation to the } \\
\text { trunk. }\end{array}$ & $\begin{array}{l}\text { Well documented } \\
\text { and tested in } \\
\text { several studies. }\end{array}$ & $\begin{array}{l}\text { Requirement of several } \\
\text { technical measures and } \\
\text { calculations means increased } \\
\text { requirements for skills and time } \\
\text { to make the estimation. }\end{array}$ & $\begin{array}{l}\text { For researchers to } \\
\text { assess individual } \\
\text { lifting situations in } \\
\text { detail. }\end{array}$ \\
\hline OCRA & $\begin{array}{l}\text { Upper } \\
\text { limb } \\
\text { load }\end{array}$ & - & $\begin{array}{l}\text { Considering all } \\
\text { repetitive tasks. } \\
\text { Easy and quick to } \\
\text { use. }\end{array}$ & $\begin{array}{l}\text { Time consuming. Allows only } \\
\text { the estimation of exposures, not } \\
\text { a precise risk evaluation. Needs } \\
\text { well trained observer. }\end{array}$ & $\begin{array}{l}\text { To Occupational } \\
\text { safety/health } \\
\text { practitioners, } \\
\text { ergonomists. }\end{array}$ \\
\hline LUBA & $\begin{array}{l}\text { Upper } \\
\text { body } \\
\text { load }\end{array}$ & $\begin{array}{l}\text { Based on } \\
\text { deviation from } \\
\text { neutral position } \\
\text { of the joints. }\end{array}$ & $\begin{array}{l}\text { Easy to use. } \\
\text { Comprehensible } \\
\text { concerning } \\
\text { postures. }\end{array}$ & $\begin{array}{l}\text { Either the right or left upper } \\
\text { limb can be assessed. Does not } \\
\text { consider force, duration and } \\
\text { repetition. }\end{array}$ & $\begin{array}{l}\text { For ergonomists } \\
\text { with limitations (the } \\
\text { method assess only } \\
\text { the postures) }\end{array}$ \\
\hline ERIN & $\begin{array}{l}\text { Upper } \\
\text { limb } \\
\text { load }\end{array}$ & $\begin{array}{l}\text { Trunk }-4, \\
\text { Shoulder/arm - } \\
5 \\
\text { Hand/Wrist }-3 \text {, } \\
\text { Neck }-3\end{array}$ & $\begin{array}{l}\text { Easy to use. } \\
\text { Difficult to } \\
\text { observe hand } \\
\text { postures. }\end{array}$ & Lower limb assessment missing. & $\begin{array}{l}\text { Can be used by } \\
\text { non-experts with } \\
\text { minimal training. }\end{array}$ \\
\hline SI & $\begin{array}{l}\text { Upper } \\
\text { limb } \\
\text { load }\end{array}$ & Hand/Wrist -5 & $\begin{array}{l}\text { Assesses all main } \\
\text { risk factors for } \\
\text { distal upper limb } \\
\text { disorders. }\end{array}$ & $\begin{array}{l}\text { Subjective assessment. Does not } \\
\text { consider vibration and contact } \\
\text { stress. Subjective assessment. }\end{array}$ & $\begin{array}{l}\text { To Occupational } \\
\text { safety/health } \\
\text { practitioners, } \\
\text { ergonomists. }\end{array}$ \\
\hline PEIL & $\begin{array}{l}\text { Upper } \\
\text { limb } \\
\text { load }\end{array}$ & $\begin{array}{l}\text { Hand/Wrist }-9, \\
\text { Trunk }-8 \\
\text { Shoulder/arm }- \\
12, \\
\text { Head/neck }-3, \\
\text { Head }-3\end{array}$ & $\begin{array}{l}\text { Exact method. } \\
\text { Easy to use. }\end{array}$ & $\begin{array}{l}\text { The method was made for } \\
\text { ergonomics analysis in } \\
\text { manufacturing companies. } \\
\text { Demands team work. }\end{array}$ & $\begin{array}{l}\text { For ergonomists } \\
\text { and practitioners. }\end{array}$ \\
\hline
\end{tabular}

\section{Legend:}

OWAS - Ovako Working Posture Assessment System, RULA - Rapid Upper Limb Assessment, REBA - Rapid Entire Body Assessment, NIOSH - National Institute of Occupational Safety and Health, OCRA - Occupational Repetitive Actions, ERIN - Evaluacion del Riesgo Individual (Individual Risk Assessment), PEIL - Potential Ergonomics Issue List, SI - Strain Index

Tab. 3. Short overview of selected methods for workplace assessment

Strain index (SI) is a semi quantitative job analysis methodology that results in a numerical score, which is believed to correlate with the risk of developing distal upper 
extremity disorders. SI was developed in USA (Moore and Garg, 1995) because previous assessment methods were subjective, lacked standardization, and did not involve examination of risk factors' interaction.

PEIL method is standardized method for ergonomic workplace assessment in all companies Johnson Controls from 1997 (Vuk, 2010). Requires team work. For effective assessment three tables are used: table A for movement repetition, table B for estimation of forces and table $\mathrm{C}$ for working postures.

\section{Comparison of methods}

As mentioned before the number of methods for body assessment at work is many. According to data available on web page of Finnish Institute of Occupational Health (http://www.ttl.fi/en/Pages/default.aspx) 28 different methods exist and the number is even greater because many of manufacturing companies use their own methods. Some of them are modified from generally known methods or even developed by their own ergonomists. (e. g. PEIL - TPV Johnson Controls, Ergocheck - BSH, Internal ergonomic assessment method - Gorenje).

In Table 3 a short overview of selected methods for workplace assessment is presented. We selected nine methods that are well documented in literature or are mostly used in Slovenian companies. Even Slovenia is small country there is no unique method for ergonomics workplace assessment but companies use different methods therefore some guidance about selected methods could be of benefit.

Most of the presented methods are quite complex for use and therefore special training is required. Regarding the specific working environment some methods are more appropriate for manufacturing companies (OWAS, PEIL, Ergocheck) and others have much better results in health care (RULA, REBA,...). Some methods can be used for a general assessment (REBA, RULA, OWAS, NIOSH), whereas other ones can also focus on assessing load or the risk for pain complaints in specific areas, such as the upper body/limb load (OCRA, LUBA, ERIN, SI and PEIL).

To analyse musculoskeletal load in different postures the time factor is also very important and should be consider. Methods usually differ if the load is static or if work is repetitive (e.g. measuring frequency of repetitions).

\section{Discussion and conclusions}

Since poorly designed workplace may have long-term negative consequences on workers' health (musculoskeletal disorders - MSDs) it is very important how a workplace is designed and organized. Methods for assessing external load are numerous and they differ in the stages of assessment. Therefore it is important to know different methods and approaches and above all which method would be the best for effective assessment.

The short review is meant to relieve the method for workplace evaluation and to broaden the knowledge about existent methods. 
Vujica Herzog, N. \& Buchmeister, B.: The Review of Ergonomics Analysis for Bo...

\section{References}

Andrejiova, M.; Kralikova, R.; Wessely, E.; Sokolova, H. (2012). Assesment of the Microclimate in the Work Environment, Chapter 42 in DAAAM International Scientific Book 2012, pp. 509-516, B. Katalinic (Ed.), Published by DAAAM International, ISBN 978-3-901509-86-5, ISSN 1726-9687, Vienna, Austria

Hignett, S.; McAtamney. L. (2000). Rapid entire body assessment (REBA). Applied Ergonomics, Vol. 31, No. 2, pp. 201-205, ISSN: 0003-6870

Karhu, U.; Kansi, P.; Kuorinka, I. (1977). Correcting working postures in industry: a practical method for analysis. Applied Ergonomics, Vol. 8, No. 4, pp. 199-201, ISSN: 0003-6870

Karhu, O.; Harkoen, R.; Sorvali, P.; Vespalainen, P. (1981). Observing working postures in industry: examples of OWAS application. Applied Ergonomics, Vol. 12, No. 1, pp. 13-17, ISSN: 0003-6870

Kee, D.; Karwowski, W. (2001). LUBA: an assessment technique for postural loading on the upper body based on joint motion discomfort and maximum holding time. Applied Ergonomics, Vol. 32, No. 4, pp. 357-366, ISSN: 0003-6870

Kee, D.; Karwowski, W. (2007). A comparison of three observational techniques for assessing postural loads in industry. International Journal of Occupational Safety and Ergonomics, Vol. 13, No. 1, pp. 3-14, ISSN: 1080-3548

McAtamney, L.; Corlett, N. (1993). RULA: a survey method for the investigation of work-related upper limb disorders. Applied Ergonomics, Vol. 24, No. 2, pp. 91-99, ISSN: 0003-6870

Moore, J.S.; Garg, A. (1995). The strain index: a proposed method to analyse jobs for risk of distal upper extremity disorders. American Industrial Hygiene Association Journal, Vol. 56, No. 5, pp. 443-458, ISSN 0002-8894

Occhipinti, E. (1998). OCRA: a concise index for assessment of exposure to repetitive movements of the upper limbs. Ergonomics, Vol. 50, No. 9, pp. 19-31, ISSN: 00140139

Occhipinti, E.; Colombini, D. (2002). Updating reference values and predictive models of the OCRA method in the risk assessment of work related musculoskeletal disorders of the upper limbs. Ergonomics, Vol. 50, No. 11, pp. 1727-1739, ISSN: 0014-0139. Polajnar, A.; Leber, M. \& Vujica Herzog, N. (2010). Muscular-skeletal diseases require scientifically designed sewing workstations. Journal of Mechanical Engineering, Vol. 56, No. 1, pp. 31-40, ISSN: 0039-2480

Rodriguez, Y.; Vina, S.; Montero, R. (2013). ERIN: A practical tool for assessing work-related musculoskeletal disorders. Occupational Ergonomics, Vol. 11, pp. 59-73. ISSN: $1359-9364$

Roman-Liu, D. (2014). Comparison of concepts in easy-to-use methods for MSD risk. Applied Ergonomics, Vol. 45, pp. 420-427, ISSN: 0003-6870

Vuk, A. (2010). Primerjalna analiza metod PEIL, RULA, REBA in OWAS za ocenjevanje obremenitev delavcev v tiskarni. Diploma work. University of Maribor Waters, T. R.; Putz-Anderson V.; Garg A.; Fine L. J. (1993). Revised NIOSH equation for the design and evaluation of manual lifting tasks. Ergonomics. Vol. 36, No. 7, pp. 749-776, ISSN: 0014-0139 